Smith, A. B., B. R. Cullis and R. Thompson (2005): The analysis of crop cultivar breeding and evaluation trials: an overview of current mixed model approaches. Journal of Agricultural Science 143: 449-462.

White, T. L., W. T. Adams and D. B. Neale (2007): Forest Genetics. CABI Publishing, CAB International, Wallingford, Oxfordshire, OX10 8DE, UK, 682 p.

White, T. L., G. R. Hodge and G. L. Powell (1993): Advanced-generation breeding strategy for slash pine in the southeastern United States. Silvae Genet. 42: 359-371.

White, T. L., A. C. Matheson, P. P. Cotterill, R. G. Johnson, A. F. Rout and D. B. Boomsma (1999): A nucleus breeding plan for radiata pine in Australia. Silvae Genet. 48: 122-133.
Woolaston, R. R., P. J. Kanowski and D. G. NiKLes (1991): Genotype-environment interaction in Pinus caribaea var. hondurensis in Queensland, Australia. II. Family x site interaction. Silvae Genet. 40: 228-232.

Wu, H. X. and A. C. MAtheson (2005): Genotype by environment interaction in an Australia-wide radiata pine diallel mating experiment: Implications for regionalized breeding. For. Sci. 5(1): 1-11.

Wu, H. X., M. Ivković, W. J. Gapare, B. S. Baltunis, M. B. Powell and T. A. McRAe (2008): Breeding for wood quality and profit in radiata pine: a review of genetic parameters. NZ J. For. Sci. 38: 56-87.

YAMADA, Y. (1962): Genotype by environment interaction and genetic correlation of the same trait under different environments. Japanese Journal of Genetics 37: 498-509.

\title{
Growth Characteristics, Physiological and Metabolic Responses of Teak (Tectona Grandis Linn. f.) Clones Differing in Rejuvenation Capacity Subjected to Drought Stress
}

\author{
By AzAmal Husen*)
}

(Received $8^{\text {th }}$ August 2009)

\begin{abstract}
Summary
Four-year old clones (FG1 and FG11) of teak (Tectona grandis Linn. f.), differing in rejuvenation capacity were grown in glazed earthenware pots. Drought treatments were imposed by withholding water for 20 days and rewatered to the field capacity daily for 5 days and the possible role of biochemical alteration and antioxidant metabolism in conferring photosynthetic capacity was determine by measuring photosynthetic traits, cellular damage and assaying activities of the superoxide dismutase (SOD) and peroxidase (PER) enzymes. Growth, relative water content (RWC), net photosynthetic rate (Pn), stomatal conductance (gs), chlorophyll fluorescence (Fv/Fm) and chlorophyll a, b, total chlorophyll and soluble protein content decreased significantly with increasing drought treatments from 5 to 20 days. Droughtinduced stress significantly increased the carotenoids content, relative electrolyte leakage and malondialdehyde (MDA) content, and, at the same time, accumulated free proline, free amino acid and soluble sugars in both clones. After re-watered to the field capacity daily for 5 days, both clones were shown significant recovery in the studied parameters. As compared with the FG11, the FG1 clone was more tolerant to drought as indicated by higher level of antioxidant enzyme activities as well as lower MDA content and electrolyte leakage. Similarly, drought stress caused less pronounced inhibition of
\end{abstract}

\footnotetext{
*) Department of Biology, Faculty of Natural and Computational Sciences, University of Gondar, P.O. Box 196, Gondar, Ethiopia. Phone: 00251-918-806304. Fax: 00251-58-1141931. E-Mail: adroot92@yahoo.co.in
}

Pn in FG1 than in FG11 clone. After re-hydration, the recovery was relatively quicker in FG1 than in FG11 clone. FG1 clone showed significant recovery in maximum quantum yield or photochemical efficiency of PSII $(\mathrm{Fv} / \mathrm{Fm})$ after 5 days of re-watering. The FG11 compared to the FG1, the former clone was less tolerant to drought than the latter. These results demonstrated that the different physiological strategies including antioxidative enzymes employed by the FG1 and FG11 clones of $T$. grandis to protect photosynthetic apparatus and alleviate drought stress. Furthermore, this study also provides ideas for teak improvement programmes and may be useful in breeding or genetic engineering for their tolerance to drought stress.

Key words: Antioxidative enzymes, Chlorophyll fluorescence, Drought stress, Leaf oxidative damage, Osmolyte accumulation, Photosynthetic capacity, Teak clones.

$\begin{array}{ll}\text { Abbreviations: Car } & \text { Carotenoids } \\ \text { Chl } & \text { Chlorophyll } \\ \text { DW } & \text { Dry weight } \\ \text { E } & \text { Transpiration rate } \\ \text { FAA } & \text { Free amino acid } \\ \text { Fv/Fm } & \begin{array}{l}\text { Maximum quantum yield or photo- } \\ \text { chemical efficiency of PSII }\end{array} \\ \text { FW } & \text { Fresh weight } \\ \text { gs } & \text { Stomatal conductance } \\ \text { MDA } & \text { Malondialdehyde } \\ \text { PER } & \text { Peroxidase } \\ \text { Pn } & \text { Net photosynthetic rate } \\ \text { RWC } & \text { Relative water content } \\ \text { SOD } & \text { Superoxide dismutase } \\ \text { TSP } & \text { Total soluble protein } \\ \text { TSS } & \text { Total soluble sugar }\end{array}$




\section{Introduction}

Among naturally occurring abiotic stresses, drought is one of the most widespread global environmental problems leading to low water availability for plants. Drought causes significant losses in growth, productivity of plants, and finally their yields (LuDLOW and Muchow, 1990; Jones and CoRLETT, 1992). Global climate change will likely make water scarcity an even greater limitation to plant productivity across an increasing amount of land. It is expected that extreme weather conditions, particularly in terms of temperature and precipitation, will be more frequent in the future. Fluctuations in water availability, including periods of drought, may become more common, and due to this the available water in the soil is reduced and adverse atmospheric conditions are cause of continuous loss of water in plants (SAXE et al., 2001). It is well known that drought affects morphological, physio-biochemical and molecular processes in plants resulting in growth inhibition, stomata closure with consecutive reduction of transpiration, decrease in chlorophyll content and inhibition of photosynthesis, protein changes and differential responses of antioxidative enzymes (ZHU, 2002; AsHRAF et al., 2004; YIN et al., 2005; DUAN et al., 2005; XIAO et al., 2008; CHAVES et al., 2009) to cope with osmotic changes in their tissues. Teak (Tectona grandis Linn. f.) wood is considered, the noblest among the all timber producing not simply because of its golden hue and wonderful texture, but even more because of its durability. It occurs naturally only in India and its neighboring countries, and is naturalized in Java, Indonesia, where it was probably introduced some 400 to 600 years ago. In addition, it has been established throughout tropical Asia, as well as in tropical Africa, Latin America and the Caribbean. Teak has also been introduced in some islands in the Pacific region and in northern Australia at trial levels. At present, it is a diverse and widely distributed genus (TEWARI, 1992; PANDEY and BROWN, 2000), and has been extensively clonally propagated (Husen and PAL, 2003a, b, c, 2006, 2007a, b, c; Husen, 2008a). Its growth is often affected by a number of ecoclimatic factors in India (TEWARI, 1992).

It is well documented fact that one of the primary physiological consequences of drought is photosynthesis inhibition (CHAVES, 1991; LAWLOR, 1995). There is now considerable consensus that reduced $\mathrm{CO}_{2}$ diffusion from the atmosphere to the site of carboxylation in the leaf, as a result of both stomatal closure and reduced mesophyll conductance, is the main cause of decreased photosynthesis under most water stress conditions (GRASSI and MAGNANI, 2005; FLEXAS et al., 2006, 2007). Stomatal closure leads to lowering of the influx of $\mathrm{CO}_{2}$ resulting in inactivation of electron transport reactions in leaves (LAWLOR, 2002). This inequity between electron transport and $\mathrm{CO}_{2}$ fixation rates may result in over-reduction of the components of the electron transport chain and hence, facilitates the transfer of electrons to reactive oxygen species (ROS), including superoxide radical, hydroxyl radical and hydrogen peroxide (BAISAK et al., 1994; Polle and RenNenberG, 1994; Iturbe-OrmaetXe et al., 1998) which ultimately leads to oxidative stress (ASADA, 1994; BAISAK et al., 1994). High concentration of
ROS causes oxidative damage to photosynthetic apparatuses, bio-molecules such as lipids, proteins and nucleic acids, leakage of electrolytes via lipid peroxidation, which results in the disruption of the cellular metabolism (ASADA, 1994; REDDY et al., 2004; ANJUM et al., 2008). Plants protect cellular and sub-cellular system including photosynthetic apparatus from the cytotoxic effects of active oxygen radicals with antioxidative enzymes such as superoxide dismutase, catalase, ascorbate peroxidase and peroxidase, and low molecular weight antioxidants (ascorbate, glutathione, proline, carotenoids, $\alpha$-tocopherols and phenolics etc.) (ALSCHER et al., 2002; REDDY et al., 2004). These components help plants to cope with the menace of ROS, thus minimizing the oxidative damages, during exposure to stress factors including drought (FOYER et al., 1994; XIAO et al., 2008, 2009). Furthermore, reports are also available on drought-induced accumulation of osmolyte compounds such as inorganic ions (especially $\mathrm{K}^{+}$), sugars and amino acids (e.g. proline) within the cell is often associated with a possible mechanism to tolerate the harmful effect of water stress (TURNER and JONES, 1980; ELSHEERY and CAO, 2008; XIAO et al., 2009). These accumulations of osmolytes in plant cells might contribute, via lowering the cell osmotic potential, to maintain several physiological processes under drought stress (BAJJI et al., 2001) or important in adaptive processes, i.e. osmotic adjustments (YIN et al., 2005; XIAO et al., 2008, 2009).

The frequency and intensity of droughts is increasing in tropical regions due to high irradiance and high temperature, which may leads to alterations in growth, photosynthesis and antioxidative defence system in various plant species. Like many other plant species that grow in the tropical environments, teak plantations are also exposed to long periods of drought stress. Therefore, it hypothesized that there would be a large set of parallel changes in the morphological, physiological and biochemical responses when plants were exposed to drought stress, these changes may enhance the capability of plants to survive and grow during drought periods. The objective of this study was to compare the effect of water-withholding and subsequent re-hydration on growth, photosynthetic gas exchange, chlorophyll fluorescence, osmotic compound accumulation, membrane peroxidation and antioxidant enzyme systems in two teak clones to determine which clone is more tolerant to drought, and to aid in breeding and genetic engineering programmes for drought resistance.

\section{Materials and Methods \\ Experimental site and plant material}

The study was conducted at the Plant Physiology nursery of New Forest campus ( $30^{\circ} 20^{\prime} 40^{\prime \prime} \mathrm{N}, 77^{\circ} 52^{\prime} 12^{\prime \prime} \mathrm{E}$ at $640 \mathrm{~m}$ above mean sea level), Forest Research Institute (FRI), Dehra Dun, India. Plantlets (clones FG 1 and FG11) of Tectona grandis Linn. f. (Verbenaceae) was obtained from the rooted cuttings (HUSEN and PAL, 2003a). The rooted cuttings were transplanted in polybags (9" x 6") in July 1999, filled with the mixture of loam soil, sand and farmyard manure in $2: 1: 1(1.5 \mathrm{~kg})$. These polybags with rooted cuttings were kept inside a 
Table 1. - Chemical and physical properties of soil (potting medium) used in the experiment.

\begin{tabular}{|l|l|}
\hline \hline Parameters & Observation \\
\hline \hline $\mathrm{pH}$ & 7.4 \\
\hline $\mathrm{N}(\%)$ & 0.12 \\
\hline $\mathrm{P}(\%)$ & 0.03 \\
\hline $\mathrm{K}(\%)$ & 0.34 \\
\hline $\mathrm{Ca}($ mequiv./100 g) & 1.85 \\
\hline $\mathrm{Mg}($ mequiv./100 g) & 0.75 \\
\hline $\mathrm{Na}($ mequiv./100 g) & 0.48 \\
\hline $\mathrm{C} \mathrm{( \% )}$ & 0.36 \\
\hline $\mathrm{Clay} \mathrm{( \% )}$ & 11.5 \\
\hline Silt (\%) & 9.2 \\
\hline Sand (\%) & 79.3 \\
\hline Soil texture & Sandy loam \\
\hline
\end{tabular}

green house; the upper portion of the green house was covered with green plastic shade, while the other parts remained open. In January 2003, both clonal materials (healthy and approximately equal height) were transferred to the glazed earthenware pots (9" x 9") @ $4.00 \mathrm{~kg}$ medium per pot. Standard method was used to analyze the soil, e.g. $\mathrm{pH}$ in water, $\mathrm{N}$ by micro-Kjeldhal method (JACKSON, 1962), P by KURTZ and BRAY method (1945), $\mathrm{C}$ by WALKLEY and BlaCK method (1934), and Ca, Mg, $\mathrm{Na}$, and $\mathrm{K}$ by atomic absorption. Soil texture was determined by the methods of Boyocous (1962). Data are presented in Table 1. Complete protection was provided against diseases and insects by foliar spray with insecticides and fungicides, as and when required. Further these plants were maintained carefully by regular watering and weeding.

\section{Growth condition and experimental design}

Experiment was executed inside the green house as described above. Four-year old healthy clones of uniform height were obtained. Drought and re-hydration treatment was conducted from 2 to 26 July 2003, twenty-five potted clones were used for each treatment and in total 125 plants of each clone (FG1 and FG11) were taken. FG1 and FG11 clones were differing in their rejuvenation capacity (HUSEN and PAL, 2003a). The completely randomized factorial design was used for this experimentation. Five replications, each of five plants ( $5 \times 5=25)$ were used for each treatment. All the plants were irrigated to the field capacity on the day prior to the start of the drought treatment. Drought was imposed by withholding water for 20 days. Immediately after these 20 days, all the plants were re-watered to the field capacity daily for 5 days (stress relief phase). Pot soil surfaces were covered with rice mulch to minimize evaporation, thus allowing a slower establishment for the water stress. The soil of the pots was mulched with plastic to avoid roots spreading into the ground. During drought and re-hydration treatment inside the green house, the relative humidity was $78 \pm 2 \%$ while maximum and minimum day/night temperature was $33 \pm 1$ and $23 \pm 1^{\circ} \mathrm{C}$ respectively.

\section{Determination of growth and physiological parameters}

The growth and physiological measurements were done on the day before treatment (control), on 5, 10, 15,
20 day since the initiation of the drought treatment and subsequent 5 day of re-hydration. The height $(\mathrm{cm})$ was measured from the ground line of earthenware pots up to the tip of FG1 and FG11 clone. Similarly, the ground line basal diameter ( $\mathrm{mm}$ ) was measured.

Net photosynthetic rate $(\mathrm{Pn})$, stomatal conductance (gs) and transpiration rate (E) were measured using a Li 6400 photosynthetic system (Li-Cor, Inc., Nebraska, USA). From each replication fully mature and expanded leaves of each clone were measured during the period of 1000 to $1200 \mathrm{~h}$ in the morning, under photosynthetic flux density of $1,000 \mu \mathrm{mol} \mathrm{m} \mathrm{m}^{-2} \mathrm{~s}^{-1}$ that was provided by a LED light source. The air humidity in the leaf chamber was about $60 \%$, with $\mathrm{CO}_{2}$ concentration of 370-380 $\mathrm{mmol} \mathrm{mol}{ }^{-1}$, with ambient air temperature of $26-28^{\circ} \mathrm{C}$, and flow rate of $500 \mu \mathrm{mol} \mathrm{s}{ }^{-1}$.

Chlorophyll fluorescence measurements were performed during 1000 to $1100 \mathrm{~h}$ in the morning with the help of a portable Hansatech Plant Efficiency Analyser (Hansatech, King's Lynn, England). The leaves were pre-darkened with leaf clips for 20 min before measurement. Fluorescence was excited by red (actinic) radiation with $650 \mathrm{~nm}$ peak wavelength obtained from light emitting diodes. The irradiance used was $2000 \mu \mathrm{mol}$ $\mathrm{m}^{-2} \mathrm{~S}^{-1}$. Maxmium quantum yield of PSII was estimated by the ratio $\mathrm{Fv} / \mathrm{Fm}=(\mathrm{Fm}-\mathrm{Fo}) / \mathrm{Fm}$ according to GENTY et al. (1989).

\section{Determination of leaf water status}

After growth, gas exchange and chlorophyll fluorescence measurements, leaf discs from the same clone (FG1 and FG11) leaves were sampled. Five replicates per clone were obtained. Leaf relative water content (RWC) was calculated as (WEATHERLEY, 1950):

$\mathrm{RWC}=[($ fresh weight - dry weight $) \div($ turgid weight dry weight)]

Turgid weight was determined by placing samples in distilled water and maintaining them at $5{ }^{\circ} \mathrm{C}$ in darkness until they reached a constant weight. Full turgor was typically reached after $12 \mathrm{~h}$. Dry weight was obtained after placing the samples in an oven at $70^{\circ} \mathrm{C}$ for $48 \mathrm{~h}$.

\section{Determination of electrolyte leakage}

Electrolyte leakage was assayed by estimating the ions leaching from leaf into distilled water (SAIRAM et al., 1998). Five replicates per clone were obtained. Leaf material of $300 \mathrm{mg}$ was taken in $10 \mathrm{ml}$ of deionized water in two sets. One set was subjected to room temperature (approximately $25^{\circ} \mathrm{C}$ ) for $4 \mathrm{~h}$ and its electrical conductivity (C1) was determined. The other set was kept in a boiling water bath $\left(100^{\circ} \mathrm{C}\right)$ for $10 \mathrm{~min}$ and its electrical conductivity was also determined (C2). Percent electrolyte leakage was calculated as below:

Electrolyte leakage $=[1-(\mathrm{C} 1 / \mathrm{C} 2)] \times 100$

Determination of photosynthetic pigments, TSP, TSS, FAA, proline, MDA content, SOD and PER enzyme activities

Fully mature and expanded leaves were randomly selected from each replication for the estimation of bio- 
chemical contents. For estimating biochemical contents in leaves five replication, each of five leaves $(5 \times 5=25)$ were randomly chosen from FG1 and FG11 clones.

The content of chlorophyll (Chl) 'a', 'b' and total Chl in leaves was analysed by keeping $0.1 \mathrm{~g}$ samples in $7 \mathrm{ml}$ of dimethyl sulfoxide (DMSO) in the oven at $65^{\circ} \mathrm{C}$ for $2 \mathrm{~h}$. Then $3 \mathrm{ml}$ of DMSO was added in $1 \mathrm{ml}$ of aliquot. Optical density was measured using Perkin Elmer UV/VIS spectrophotometer Lamda 25 (HISCOX and IsRAELSTAM, 1979). The contents of Chl 'a', 'b' and total Chl were estimated by the formula given by DUXBURY and YENTSCH (1956) and MACLACHLAN and ZALICK (1963) respectively.

The content of total soluble proteins (TSP) in leaves was measured in phosphate buffer extracts at $595 \mathrm{~nm}$ after reaction with trichloroacetic acid (TCA) and Bradford reagent (BRADFORD, 1976). Bovine serum albumin was used as a standard. The amount of TSP was expressed as $\mathrm{mg} \mathrm{g}^{-1} \mathrm{FW}$.

Extracts from leaves were prepared as per the method described by SAWHNEY et al. (1968), and total soluble sugars (TSS) content was estimated by the phenol-sulfuric-acid method (DuBoIs et al., 1956). The amount of TSS was expressed as $\mathrm{mg} \mathrm{g}^{-1} \mathrm{DW}$.

Free amino acids in leaves were determined using the method suggested by LEE and TAKAHASHI (1966). The amount of free amino acids was expressed as $\mathrm{mg} \mathrm{g}^{-1} \mathrm{FW}$.

Extraction and estimation of free proline were conducted according to the procedures described by BATES et al. (1973). The corresponding concentration of proline was determined against the standard curve processed in the same manner by using L-proline. The amount of proline in leaf samples was expressed as $\mu \mathrm{mol} \mathrm{g}^{-1} \mathrm{FW}$.

Leaf oxidative damage to lipids was expressed as equivalents to malondialdehyde (MDA). Its content was determined as described by HoDGEs et al. (1999) with slight modification, for taking into account the possible influence of interfering compounds in the assay for thiobarbituric acid (TBA)-reactive substances. Leaf tissues were repeatedly extracted with $4 \mathrm{ml} 5 \%$ (w/v) TCA. The homogenate was centrifuged at $15,000 \mathrm{xg}$ for $15 \mathrm{~min}$ and an aliquot of appropriately diluted sample was added to a test tube with an equal volume of either: (1) TBA solution containing $20 \%(\mathrm{w} / \mathrm{v})$ TCA and $0.01 \%$ butylated hydroxytoluene (BHT), or (2) +TBA solution containing the above solution plus $0.65 \%(\mathrm{w} / \mathrm{v})$ TBA. Samples were heated at $95^{\circ} \mathrm{C}$ for $25 \mathrm{~min}$, and then cooled immediately. The absorbance was read at 440 , 532 and $600 \mathrm{~nm}$ using Perkin Elmer UV/VIS spectrophotometer Lamda 25. MDA equivalents were calculated as $10^{6} \mathrm{x}[(\mathrm{A}-\mathrm{B}) / 157,000]$, where $\mathrm{A}=\left[\left(\mathrm{OD}_{532}+\mathrm{TBA}\right)\right.$ $\left.-\left(\mathrm{OD}_{600}+\mathrm{TBA}\right)-\left(\mathrm{OD}_{532}-\mathrm{TBA}-\mathrm{OD}_{600}-\mathrm{TBA}\right)\right]$, and $\mathrm{B}=\left[\left(\mathrm{OD}_{440}+\mathrm{TBA}-\mathrm{OD}_{600}+\mathrm{TBA}\right) \times 0.0571\right]$.

An enzyme extract for superoxide dismutase (SOD) at a cold temperature was prepared by first freezing a weighed amount of leaf sample $(1 \mathrm{~g})$ in liquid nitrogen to prevent proteolytic activity, followed by grinding with $10 \mathrm{ml}$ of extraction buffer $(0.1 M$ phosphate buffer, pH7.5, containing $0.5 \mathrm{~m} M$ EDTA and $1 \mathrm{~m} M$ ascorbic acid). Brie was passed through four layers of cheesecloth and filtrate was centrifuged for $20 \mathrm{~min}$ at $15,000 \mathrm{xg}$, $4^{\circ} \mathrm{C}$ and the supernatant was used as enzyme (Proc-
HAZKOVA et al., 2001). SOD activity was estimated by recording the decrease in optical density of nitroblue tetrazolium dye by the enzyme (DHINDSA et al., 1981). Three millilitres of the reaction mixture contained $13 \mathrm{~m} M$ of methionine, $25 \mathrm{~m} M$ of nitroblue tetrazolium chloride, $0.1 \mathrm{~m} M$ of EDTA, $50 \mathrm{~m} M$ of phosphate buffer (pH7.8), $50 \mathrm{~m} M$ of sodiumcarbonate and $0.1 \mathrm{ml}$ of enzyme. The reaction was started by adding $2 \mathrm{~m} M$ of riboflavine and placing the tubes under two $15 \mathrm{~W}$ fluorescent lamps for $15 \mathrm{~min}$. A complete reaction mixture without enzyme, which gave the maximal colour, served as a control. The reaction was stopped by switching off the light and placing the tubes in the dark. A non-irradiated complete reaction mixture served as a blank. The absorbance was recorded at $560 \mathrm{~nm}$ using Perkin Elmer UV/VIS spectrophotometer Lamda 25, and one unit of enzyme activity was taken as that amount of enzyme which reduced the absorbance reading to $50 \%$ in comparison with tubes lacking enzyme.

Peroxidase (PER) enzyme activity was measured using guaiacol as substrate following the methods of Husen (2008b). The assay mixture contained $0.1 \mathrm{M}$ phosphate buffer ( $\mathrm{pH}$ 6.1), $4.0 \mathrm{mM}$ guaiacol as donor, $3.0 \mathrm{mM} \mathrm{H} \mathrm{H}_{2} \mathrm{O}_{2}$ as substrate, and $0.4 \mathrm{ml}$ crude enzyme extract. The total reaction volume was $1.2 \mathrm{ml}$. The optical density was measured at $420 \mathrm{~nm}$ using a Perkin Elmer UV/VIS spectrophotometer Lamda 2S. The enzyme activity was expressed as the rate of optical density change $\mathrm{min}^{-1} \mathrm{mg}^{-1}$ protein (BARNETT, 1974).

\section{Statistical analysis}

Statistical analysis was performed with the Statistical Package for Social Sciences (SPSS) windows ${ }^{\circledR}$ software package. The data recorded on the growth, physiological and biochemical parameters were subjected to two-way ANOVA. Means were compared by using Tukey's test at significance level $\mathrm{P}<0.05$ (the same letters indicate that means within a row or column are not significantly different at $\mathrm{P}>0.05$ level).

\section{Results \\ Growth parameters, relative water content and photosynthetic traits}

Plant height and basal diameter of two clones showed a significant relationship with increasing number of days since drought treatment (Table 2 and 3). After 20 days withholding water, plant growth in terms of height of FG1 and FG11 were $1.22 \%$ and $0.61 \%$ respectively compared to control. In contrast, basal diameter increment of FG1 and FG11 were $1.52 \%$ and $2.07 \%$, respectively compared to control. The interaction effect between clone and drought treatment was significant for height increment (Table 3).

Relative water content (RWC) of two clones progressively decreased with increasing number of days since drought treatment (Table 2). After 20 days withholding water, compared to control, the decrease in leaves RWC was more in FG11 (51.56\%) than FG1 (49.59\%). After re-watering for 5 days, a full recovery of leaf water status was achieved in FG1 while at the same time FG11 did not show complete recovery. The interaction effect 
Table 2. - Growth, relative water content (RWC), net photosynthetic rate (Pn), stomatal conductance (gs), transpiration rate $(\mathrm{E})$, chlorophyll fluorescence $(\mathrm{Fv} / \mathrm{Fm})$, photosynthetic pigments (Chl a, b, total Chl and Car) and protein (TSP) in two clone of Tectona grandis on the day before treatment (control), 5, 10, 15, 20 th day since the start of the drought treatment and on $5^{\text {th }}$ day of re-hydration (RHD). Values followed by the same letter indicate no significant differences at $\mathrm{P}<0.05$ level according to Tukey's test. Each value represents the mean $\pm \mathrm{SE}$ of five replicates.

\begin{tabular}{|c|c|c|c|c|c|c|c|}
\hline \multirow{2}{*}{ Parameters } & \multirow[t]{2}{*}{ Clone } & \multicolumn{6}{|c|}{ Drought treatments } \\
\hline & & Control & 5 & 10 & 15 & 20 & RHD \\
\hline \multirow{2}{*}{ Height (cm) } & FG1 & $92.34 \pm 1.11 \mathrm{a}$ & $93.08+1.13 \mathrm{a}$ & $93.35 \pm 1.05 \mathrm{ab}$ & $93.42 \pm 1.28 \mathrm{~b}$ & $93.47 \pm 1.14 \mathrm{~b}$ & $93.65 \pm 1.20 \mathrm{c}$ \\
\hline & FG1 1 & $92.07 \pm 1.23 \mathrm{a}$ & $92.23 \pm 1.16 \mathrm{a}$ & $92.49 \pm 1.09 \mathrm{a}$ & $92.57 \pm 1.15 \mathrm{a}$ & $92.63 \pm 1.10 \mathrm{~b}$ & $92.79 \pm 1.25 \mathrm{~b}$ \\
\hline \multirow[t]{2}{*}{ Basal diamcter (mm) } & FG1 & $9.87 \pm 0.09 \mathrm{a}$ & $9.92 \pm 0.08 \mathrm{a}$ & $9.98 \pm 0.09 \mathrm{a}$ & $10.00 \pm 0.09 \mathrm{~b}$ & $10.02 \pm 0.09 \mathrm{~b}$ & $10.07 \pm 0.07 \mathrm{~b}$ \\
\hline & FG11 & $9.64 \pm 0.07 \mathrm{a}$ & $9.76 \pm 0.03 \mathrm{a}$ & $9.81 \pm 0.05 \mathrm{a}$ & $9.82 \pm 0.03 \mathrm{a}$ & $9.84 \pm 0.08 \mathrm{ab}$ & $9.89 \pm 0.04 \mathrm{~b}$ \\
\hline \multirow[t]{2}{*}{ RWC (\%) } & FGl & $70.34 \pm 1.81 \mathrm{a}$ & $67.75 \pm 1.60 \mathrm{a}$ & $51.17 \pm 1.62 b$ & $43.88 \pm 1.12 \mathrm{c}$ & $35.46 \pm 1.42 \mathrm{~d}$ & $69.87 \pm 1.83 a$ \\
\hline & FGl I & $69.14 \pm 2.01 \mathrm{a}$ & $60.53 \pm 1.37 \mathrm{~b}$ & $48.65 \pm 1.41 \mathrm{c}$ & $40.10 \pm 0.91 \mathrm{~d}$ & $33.49 \pm 1.36 \mathrm{e}$ & $66.86 \pm 1.3 \mathrm{lb}$ \\
\hline \multirow[t]{2}{*}{ Chl a $\left(\mathrm{mg} \mathrm{g}^{-1} \mathrm{FW}\right)$} & FG1 & $0.46 \pm 0.011 \mathrm{a}$ & $0.42 \pm 0.010 \mathrm{a}$ & $0.33 \pm 0.011 \mathrm{~b}$ & $0.29 \pm 0.008 \mathrm{c}$ & $0.24 \pm 0.011 \mathrm{c}$ & $0.43 \pm 0.026 a$ \\
\hline & FGII & $0.45 \pm 0.016 \mathrm{a}$ & $0.39 \pm 0.015 b$ & $0.31 \pm 0.009 b$ & $0.27 \pm 0.011 \mathrm{c}$ & $0.23 \pm 0.021 \mathrm{c}$ & $0.41 \pm 0.016 \mathrm{~b}$ \\
\hline \multirow[t]{2}{*}{ Chl b (mg g $\mathrm{FW})$} & FG1 & $0.37 \pm 0.012 \mathrm{a}$ & $0.33 \pm 0.011 \mathrm{a}$ & $0.29 \pm 0.011 \mathrm{~b}$ & $0.21 \pm 0.018 \mathrm{c}$ & $0.19 \pm 0.008 \mathrm{c}$ & $0.36 \pm 0.015 \mathrm{a}$ \\
\hline & FG11 & $0.36 \pm 0.010 \mathrm{a}$ & $0.31 \pm 0.017 \mathrm{~b}$ & $0.28 \pm 0.013 b$ & $0.20 \pm 0.015 \mathrm{c}$ & $0.18 \pm 0.011 \mathrm{c}$ & $0.34 \pm 0.016 \mathrm{a}$ \\
\hline \multirow[t]{2}{*}{ Total Chl $\left(\mathrm{mg} \mathrm{g}^{-1} \mathrm{FW}\right)$} & FGI & $0.89 \pm 0.011 \mathrm{a}$ & $0.82 \pm 0.019 \mathrm{a}$ & $0.71 \pm 0.023 \mathrm{c}$ & $0.60 \pm 0.008 \mathrm{~d}$ & $0.50 \pm 0.015 \mathrm{~d}$ & $0.83 \pm 0.021 \mathrm{a}$ \\
\hline & FG11 & $0.87 \pm 0.011 \mathrm{a}$ & $0.80 \pm 0.015 b$ & $0.70 \pm 0.015 \mathrm{c}$ & $0.58 \pm 0.008 \mathrm{~d}$ & $0.48 \pm 0.021 \mathrm{~d}$ & $0.82 \pm 0.022 \mathrm{ab}$ \\
\hline \multirow[t]{2}{*}{$\operatorname{Car}\left(\mathrm{mg} \mathrm{g}^{-1} \mathrm{FW}\right)$} & FG1 & $0.32 \pm 0.013 \mathrm{a}$ & $0.36 \pm 0.014 \mathrm{~b}$ & $0.41 \pm 0.016 \mathrm{c}$ & $0.47 \pm 0.015 \mathrm{~d}$ & $0.57 \pm 0.021 \mathrm{e}$ & $0.39 \pm 0.018 \mathrm{~b}$ \\
\hline & FGl I & $0.32 \pm 0.015 \mathrm{a}$ & $0.35 \pm 0.021 \mathrm{a}$ & $0.40 \pm 0.012 b$ & $0.46 \pm 0.023 \mathrm{c}$ & $0.56 \pm 0.017 \mathrm{e}$ & $0.38 \pm 0.024 b$ \\
\hline \multirow[t]{2}{*}{$\operatorname{Pn}\left(\mu \mathrm{mol} \mathrm{m} \mathrm{m}^{-2} \mathrm{~s}^{-1}\right)$} & FG1 & $8.87 \pm 0.02 a$ & $6.98 \pm 0.04 b$ & $5.99 \pm 0.06 \mathrm{c}$ & $4.64 \pm 0.08 \mathrm{~d}$ & $2.73 \pm 0.04 \mathrm{e}$ & $6.50 \pm 0.10 \mathrm{~b}$ \\
\hline & FGl l & $8.66=0.04 a$ & $6.85 \pm 0.05 b$ & $5.43 \pm 0.07 \mathrm{c}$ & $4.30 \pm 0.11 \mathrm{~d}$ & $2.23+0.06 \mathrm{e}$ & $5.96+0.09 \mathrm{bc}$ \\
\hline \multirow[t]{2}{*}{ gs $\left(\mathrm{mol} \mathrm{m}^{-2} \mathrm{~s}-1\right)$} & FGl & $0.195 \pm 0.010 \mathrm{a}$ & $0.152 \pm 0.016 \mathrm{~b}$ & $0.115 \pm 0.003 \mathrm{c}$ & $0.083 \pm 0.002 \mathrm{~d}$ & $0.034 \pm 0.013 \mathrm{e}$ & $0.145 \pm 0.017 \mathrm{~b}$ \\
\hline & FG11 & $0.203 \pm 0.011 \mathrm{a}$ & $0.147 \pm 0.011 \mathrm{~b}$ & $0.093 \pm 0.002 \mathrm{c}$ & $0.076 \pm 0.001 \mathrm{~d}$ & $0.028 \pm 0.009 \mathrm{e}$ & $0.123 \pm 0.013 \mathrm{bc}$ \\
\hline \multirow[t]{2}{*}{$\mathrm{E}\left(\mu \mathrm{mol} \mathrm{m} \mathrm{m}^{-2} \mathrm{~s}^{-1}\right)$} & FG1 & $2.12 \pm 0.11 \mathrm{a}$ & $1.93 \pm 0.12 b$ & $1.09 \pm 0.11 \mathrm{c}$ & $0.97 \pm 0.09 \mathrm{~d}$ & $0.59 \pm 0.02 \mathrm{e}$ & $2.03 \pm 0.09 \mathrm{~b}$ \\
\hline & FG11 & $2.10 \pm 0.15 \mathrm{a}$ & $1.91 \pm 0.15 b$ & $1.05 \pm 0.15 \mathrm{c}$ & $0.88 \pm 0.05 \mathrm{~d}$ & $0.56 \pm 0.06 \mathrm{e}$ & $2.04 \pm 0.11 \mathrm{~b}$ \\
\hline \multirow[t]{2}{*}{$\mathrm{Fv} / \mathrm{Fm}$} & FGl & $0.794 \pm 0.004 \mathrm{a}$ & $0.751 \pm 0.003 \mathrm{a}$ & $0.669 \pm 0.001 \mathrm{~b}$ & $0.634 \pm 0.011 \mathrm{c}$ & $0.614 \pm 0.007 \mathrm{c}$ & $0.776 \pm 0.015 \mathrm{a}$ \\
\hline & FG1 I & $0.793 \pm 0.005 a$ & $0.734 \pm 0.007 \mathrm{a}$ & $0.65 \mathrm{l} \pm 0.002 \mathrm{~b}$ & $0.630 \pm 0.031 \mathrm{c}$ & $0.608 \pm 0.010 \mathrm{~d}$ & $0.720 \pm 0.012 \mathrm{~b}$ \\
\hline \multirow[t]{2}{*}{ TSP $\left(\mathrm{mg} \mathrm{g}^{-1} \mathrm{FW}\right)$} & FG1 & $61.37 \pm 2.77 \mathrm{a}$ & $58.43 \pm 2.34 \mathrm{~b}$ & $52.62 \pm 2.45 \mathrm{c}$ & $44.35 \pm 1.80 \mathrm{~d}$ & $37.27 \pm 1.51 \mathrm{e}$ & $55.27 \pm 2.14 \mathrm{~b}$ \\
\hline & FGl1 & $60.32 \pm 2.50 \mathrm{a}$ & $58.27 \pm 2.09 \mathrm{~b}$ & $51.19 \pm 2.37 \mathrm{c}$ & $43.92 \pm 1.57 \mathrm{~d}$ & $36.91 \pm 1.72 \mathrm{e}$ & $52.11 \pm 1.75 b c$ \\
\hline
\end{tabular}

between clone and drought treatment was also significant for RWC (Table 3).

Chlorophyll (Chl) a, b and total Chl were reduced severely with increasing number of days since drought treatment (Table 2) in both clones. After 20 days withholding water, content of Chl a in FG1 and FG11 were $47.83 \%$ and $48.89 \%$ respectively, compared to control. After 5 days of re-watering a full recovery in content of Chl a was achieved in FG1 while at the same time FG11 did not show complete recovery. After 20 days withholding water, in FG1, the decrease in Chl b was $48.65 \%$, and in FG11 was $50.00 \%$. However, after 5 days of rewatering, content of $\mathrm{Chl} \mathrm{b}$ was fully recovered in both clones. Total Chl content, after 20 days withholding, the decrease in FG1 and FG11 were $43.82 \%$ and $44.83 \%$ respectively, compared to control. After 5 days of rewatering, total Chl was fully recovered in FG1 while, FG11 show partial recovery. Drought treatment significantly increased the carotenoids (Car) content in both clones. The increase in FG1 and FG11 were $78.13 \%$ and $75.00 \%$, respectively. However, after re-watering for 5 days, both clones did not show complete recovery in content of Car.

Exposing 20 days of drought treatment over teak clones produced significant changes in the net photosynthetic rate $(\mathrm{Pn})$, stomatal conductance (gs) and transpiration rate $(\mathrm{E})$ chlorophyll fluorescence $(\mathrm{Fv} / \mathrm{Fm})$ (Table 2 and 3). The decrease of $\mathrm{Pn}$, gs and $\mathrm{E}$ in FG1 were $69.22 \%, 82.56 \%$, and $72.17 \%$, respectively as compared to control. However, in FG11, the decrease of Pn, gs and E were $74.25 \%, 86.21 \%$ and $73.33 \%$, respectively. FG11 was more affected by drought treatment than FG1 clones. Both clones did not show a complete recovery after 5 days of re-watering as indicated by the restitution of water status and gas exchange rates to the control values. Inhibition of photosynthetic rate was accompanied by parallel decrease in chlorophyll fluorescence (Fv/Fm). After 20 days withholding water, Fv/Fm values decreased by $22.67 \%$ in FG1 and by $23.33 \%$ in FG11. After 5 days of re-watering a full recovery in $\mathrm{Fv} / \mathrm{Fm}$ was achieved in FG1 while at the same time FG11 did not show complete recovery (Table 2). The interaction effect between clone and drought treatment was significant for $\mathrm{Pn}$, gs, E and Fv/Fm (Table 3).

The content total soluble protein (TSP) was sensitive to drought treatment. As shown in Table 3, treatment with drought stress at 20 days withholding water, gradually decrease the content of TSP. Content of TSP decreased by $39.27 \%$ and $38.81 \%$ in FG1 and FG11 clones, respectively. This decrease of TSP was more in FG11. TSP content in both clones did not show a complete recovery after 5 days of re-watering as compared to the control values. However, TSP recovery was near to the 5 days withholding water, i.e. drought treatment.

\section{Osmotic adjustment}

Exposing the teak clones to the drought treatment caused a significant change in proline, free amino acids (FAA) and total soluble sugar (TSS) content (Figure 1 and Table 3). The content of proline, FAA and TSS were increased progressively during the withholding water in both the clones. On 20 days, proline content increased by $87.09 \%$ in FG1 and by $82.09 \%$ in FG11. At the same time, FAA content increase by $60.18 \%$ in FG1 and by 
Table 3. - ANOVA result on the effect of clone, drought treatment and their combination on various growth, physiological and biochemical parameters (MSS mean square value; ${ }^{*}$ and $* *$ significance level at $\mathrm{P}<0.05$ and $\mathrm{P}<0.01$ respectively; ns non significant).

\begin{tabular}{|c|c|c|c|c|c|c|c|c|c|}
\hline \multirow[t]{2}{*}{ Parameters } & \multicolumn{3}{|c|}{ Clone (C) } & \multicolumn{3}{|c|}{ Drought treatment (D) } & \multicolumn{3}{|c|}{$\mathrm{C} \times \mathrm{D}$} \\
\hline & MSS & $\mathrm{P}<0.05$ & $P<0.01$ & MSS & $\mathrm{P}<$ & $\mathrm{P}<0.01$ & MSS & $P<0.05$ & $P<0.01$ \\
\hline Height & 8.57 & - & $* *$ & 1.32 & - & $* *$ & 0.14 & $*$ & - \\
\hline Basal diameter & 0.498 & - & $* *$ & 0.067 & - & $* *$ & 0.002 & ns & ns \\
\hline $\mathrm{RWC}$ & 161.77 & - & $* *$ & 2191.41 & - & $* *$ & 11.23 & - & $* *$ \\
\hline Pn & 2.147 & - & $* *$ & 46.061 & - & ** & 0.080 & - & *** \\
\hline Gs & 0.0012 & $*$ & - & 0.0341 & - & ** & 0.0003 & * & - \\
\hline $\mathrm{E}$ & 0.013 & - & - & 4.372 & $*$ & - & 0.002 & $*$ & - \\
\hline $\mathrm{Fv} / \mathrm{Fm}$ & 0.0014 & $*$ & - & 0.0594 & - & $* *$ & 0.0001 & $*$ & ns \\
\hline Chl 'a' & 0.0032 & - & $* *$ & 0.1079 & - & $* *$ & 0.0001 & $\mathrm{~ns}$ & $\mathrm{~ns}$ \\
\hline Chl 'b' & 0.0020 & - & $* *$ & 0.0789 & - & $* *$ & 0.0002 & ns & ns \\
\hline Total Chl & 0.0041 & - & *** & 0.4081 & - & *** & 0.0001 & ns & ns \\
\hline Car & 0.0005 & - & - & 0.0759 & - & $* *$ & 0.0001 & ns & ns \\
\hline TSP & 8.84 & - & $* *$ & 811.50 & - & ** & 0.66 & $\mathrm{~ns}$ & ns \\
\hline TSS & 7.16 & $*$ & - & 714.77 & - & $* *$ & 0.48 & ns & ns \\
\hline FAA & 0.18 & - & - & 15.44 & - & $* *$ & 0.03 & ns & ns \\
\hline Proline & 0.002 & - & - & 11.338 & - & $* *$ & 0.001 & ns & ns \\
\hline MDA & 0.0087 & - & - & 170.0717 & - & $* *$ & 0.0006 & $\mathrm{~ns}$ & $\mathrm{~ns}$ \\
\hline Electrolyte leakage & 8.50 & - & $* *$ & 172.66 & - & $* *$ & 1.52 & - & $* *$ \\
\hline SOD & 38.18 & - & - & 214642.63 & - & $* *$ & 2.02 & ns & ns \\
\hline PER & 0.0016 & - & - & 0.0051 & - & $* *$ & 0.0001 & ns & ns \\
\hline
\end{tabular}

$59.34 \%$ in FG11. After 5 days of re-watering, both clones show a complete recovery in content of proline. While, FG11 shows incomplete recovery in FAA content as compared with the control. In terms of recovery, the value of FAA content in FG11 was near to the 5 days withholding water, i.e. drought treatment. Drought treatment also, leads to an increase in TSS content by $27.36 \%$ in FG1 and by $26.81 \%$ in FG11. After 5 days of re-watering, both FG1 and FG11 teak clones did not show a complete recovery. However, TSS content recovery situation was near to the 5 days withholding water.

\section{Electrolyte leakage and leaf oxidative damage}

To evaluate the drought stress-induced oxidative damage to membranes, the electrolyte leakage, which is an indicator of lipid peroxidation, and malondialdehyde (MDA) which is a product of lipid peroxidation, were determined. Due to exposure of drought treatment caused a significant increase in electrolyte leakage as well as MDA (Figure 2 and Table 3). The increase in electrolyte leakage in FG1 was found $72.29 \%$, while in FG11 accumulated $89.05 \%$ as compared with the control. However, after re-watering for 5 days, FG11 clones did not show complete recovery. Further there was a significant interaction effect between clone and drought treatment in electrolyte leakage from the leaves of teak (Table 3). The increase MDA content was noticed by $172.73 \%$ in FG1 and by $182.78 \%$ in FG11, after 20 days withholding water. Both FG1 and FG11 clones shows a complete recovery after 5 days of re-watering as compared to the control values of MDA content.

\section{Enzymatic antioxidant activities}

The significant drought treatment responses on activities of superoxide dismutase (SOD) and peroxidase
(PER) enzymes were noted in both FG1 and FG11 clones (Figure 3 and Table 3). After 20 days withholding water resulted in elevated expression of SOD activity by $67.50 \%$ and $64.12 \%$ for FG1 and FG11 clone, respectively. After 5 days of re-watering, FG1 had higher SOD antioxidant activity than FG11 clones and did not show a complete recovery as compared with the control. Similar trend of variation was noticed for PER activity, it increased by $27.53 \%$ and $25.44 \%$ in FG1 and FG11 clone, respectively. After 5 days of re-watering, FG11 clone show a complete recovery, while FG1 was not fully recovered. However, in FG1 clone, the PER activity recovery was near to the 5 days withholding water condition. Both SOD and PER antioxidant activity was found higher in FG1 clones during the drought treatment and also after 5 days of re-hydration.

\section{Discussion}

The availability of water is one of the major limiting factors for normal plant growth. Plants growing in tropical climate often face certain degree of drought stress. As a result, it influences plant growth by affecting cell division, enlargement and differentiation and also the plant genetic make-up (PATEL and GoLAKIA, 1988). In the present study, drought stress significantly slows down and reduced the plant height and basal diameter in both the clone of teak. This may be due to the avoidance mechanism through adjustment of plant growth rate or decreased rate of photosynthesis. Reduction in terms of growth was obtained for many other plant species (ZHANG et al., 2005; YIN et al., 2005; XIAO et al., 2009). In this study, RWC in leaves decreased significantly. However, RWC was more reduced in FG11 than FG1 clone. After 5 days of re-hydration FG11 did not show complete recovery, this suggests that FG1 needs 
lower RWC maintenance. Drought stress-induced decrease in RWC has been reported in many previous studies (DUAN et al., 2005; ElSHEERY and CAO, 2008; XIAO et al., 2009).

The contents of photosynthetic pigments in plants subjected to drought stress are known to decline (DUAN et al., 2005; ELSHEERY and CAO, 2008). Drought condi- tion decreased the chlorophyll content considerably in both the teak clones. This may be due to reduction in the lamellar content of the light harvesting $\mathrm{Chl} \mathrm{a/b}$ protein that accounts for the elevated $\mathrm{Chl} \mathrm{a} / \mathrm{b}$ ratio $(2.8: 4.5)$ and/ or due to water stress-induced decrease in the availability of mineral nutrients, and/or to the damages to chloroplasts by ROS, and or either slow synthesis or
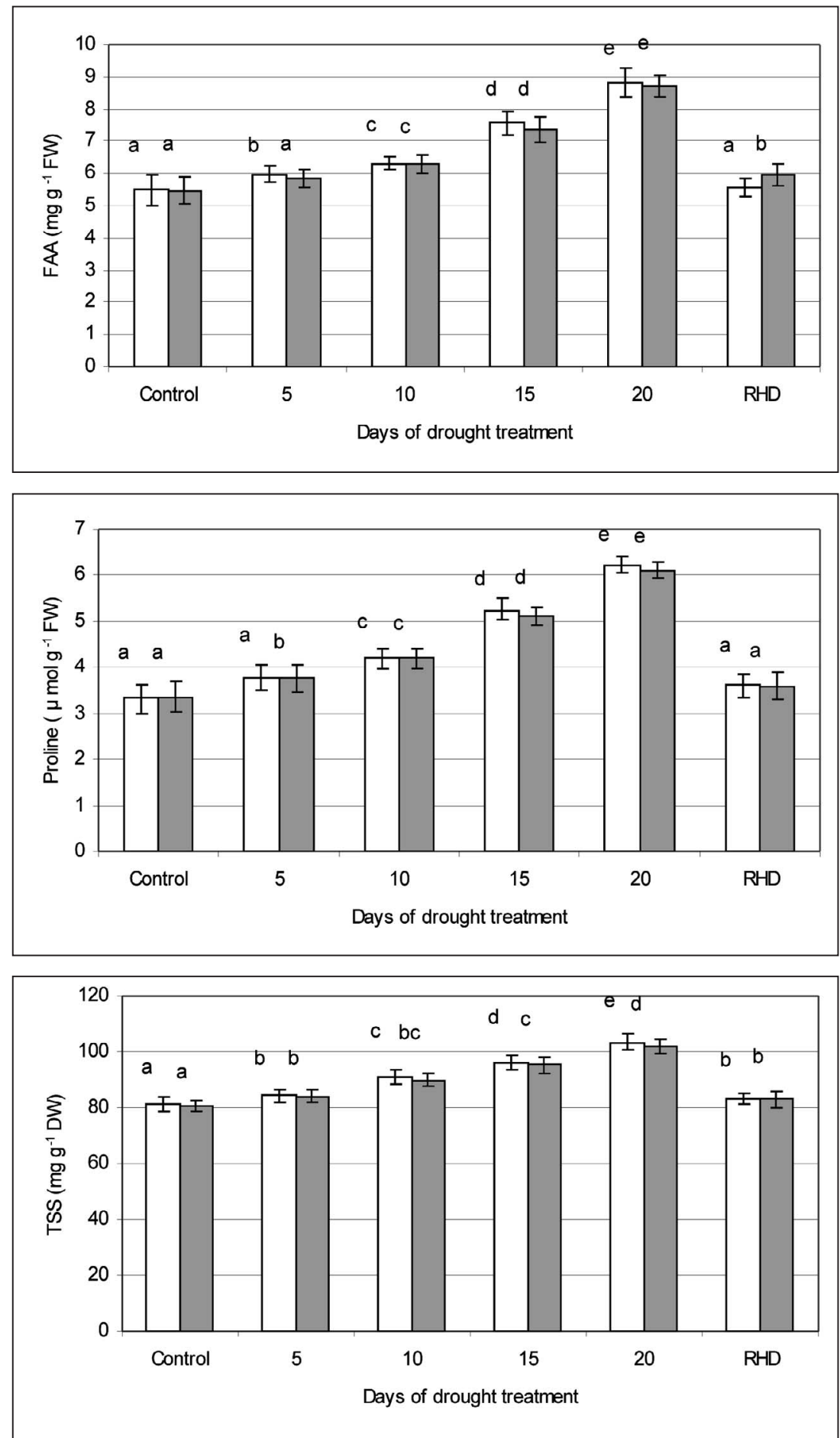

Figure 1. - The content of free amino acids (FAA), proline and total soluble sugars (TSS) in two clones of Tectona grandis (FG1 white bars and FG11 gray bars) on the day before treatment (Control), $5,10,15,20^{\text {th }}$ day since drought treatment and $5^{\text {th }}$ day since re-hydration (RHD). Values followed by the same letter indicate no significant differences at $\mathrm{P}<0.05$ level according to Tukey's test. Each value represents the mean $\pm \mathrm{SE}$ of five replicates. 

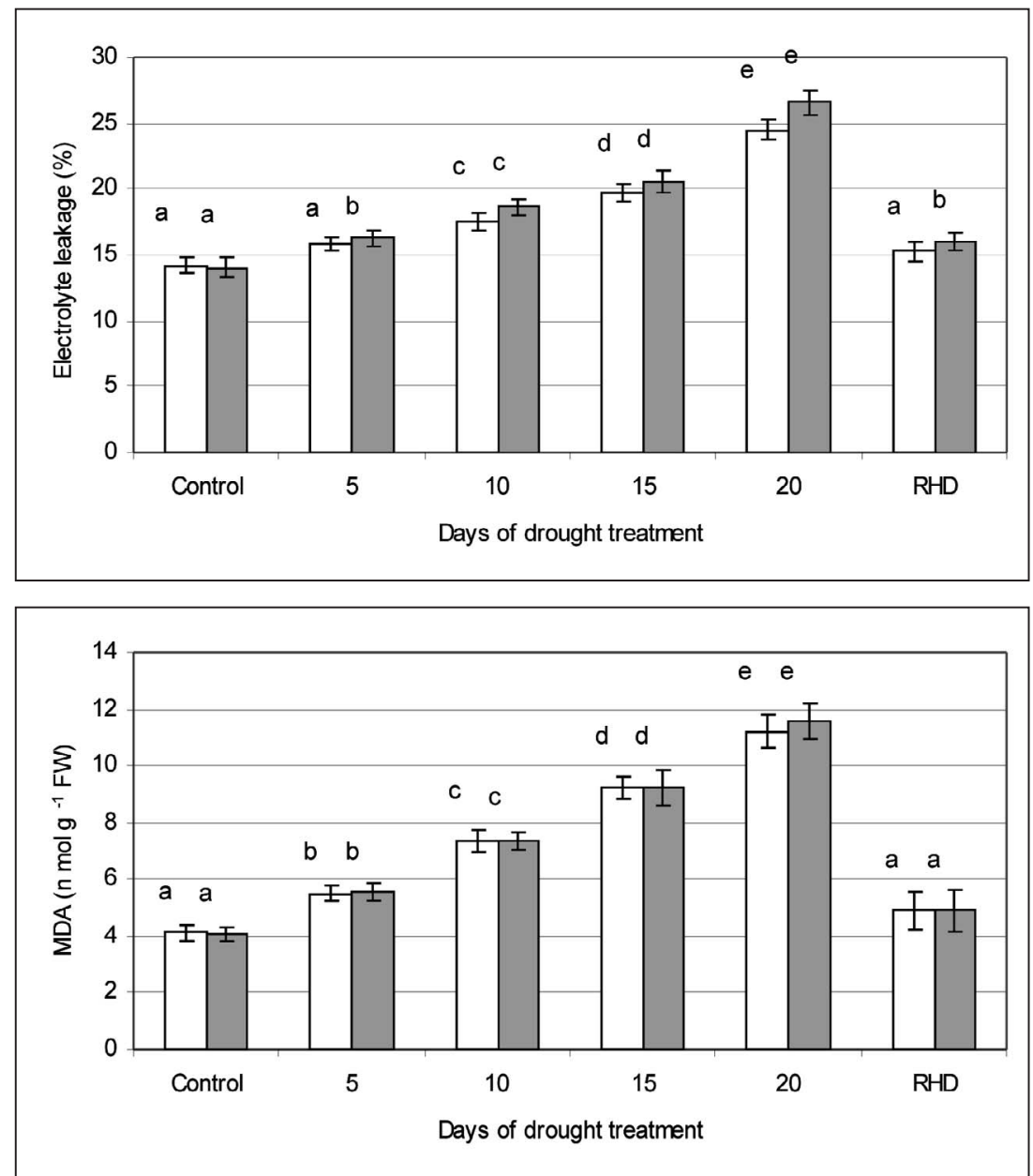

Figure 2. - Electrolyte leakage and content of malondialdehyde (MDA) in two clones of Tectona grandis (FG1 white bars and FG11 gray bars) on the day before treatment (Control), $5,10,15,20^{\text {th }}$ day since drought treatment and $5^{\text {th }}$ day since re-hydration (RHD). Values followed by the same letter indicate no significant differences at $\mathrm{P}<0.05$ level according to Tukey's test. Each value represents the mean $\pm \mathrm{SE}$ of five replicates.

fast breakdown of chlorophyll pigments (KHANNACHOPRA et al., 1980; AsHraF, 2003). However in contrast, carotenoid contents significantly increased in both FG1 and FG11 clones. This confirm to earlier report on Populus cathayana, where under moderate drought stress carotenoids contents was increased (XIAO et al., 2008). The carotenoids content has essential functions in photosynthesis and photoprotection. In addition to structural roles, they are well known for their antioxidant activity by quenching ${ }^{3} \mathrm{Chl}$ and ${ }^{1} \mathrm{O}_{2}$, inhibiting lipid peroxidation, and stabilizing membranes (DEMMIG-ADAMS and AdAMs, 1992; Frank and Cogdell, 1996; NiYogi, 1999). Carotenoids also play a critical role in the assembly of the light-harvesting complex and in the radiationless dissipation of excess energy (STREB et al., 1998; MUNNÉBosch and Alegre, 2000).

In the present study, Pn, gs, E decreased significantly under drought stress. Reductions in the photosynthetic activity induced by drought were first triggered by stomatal closure, resulting in limitation of ambient $\mathrm{CO}_{2}$ diffusion to the mesophyll and thus reduction of photosynthesis. Further, results showed that gs was more sensi- tive in response to drought treatment before the change in the leaf water content is detectable, as has been also shown in other species (Gollan et al., 1985; Socías et al., 1997). This reveals that these teak clones employ the physiologically drought-avoidance strategy (GULIAS et al.. 2002). At later stage of drought treatment, the Pn reduction may be caused by both stomatal and nonstomatal mechanisms (EPRON et al., 1992; MAXWELL and JoHnson, 2000). After 5 days of re-watering, gas exchange parameters did not show a complete recovery may be due to limitation of stomatal and mesophyll conductance and biochemical limitations (GALMÉs et al., 2007). In many species, PSII is quite resistant to drought (GENTY et al., 1987; CoRNIC et al., 1992). Maximum quantum yield of PSII (Fv/Fm) did not change significantly under moderate drought stress in both clones, indicating no photodamage to PSII reaction centers (FOYER et al., 1994). After 5 days of re-watering, both clones showed rapid recovery in $\mathrm{Fv} / \mathrm{Fm}$ in parallel with that of Pn. However, FG1 teak clones recovered completely, but FG11 was recovered only up to the moderate drought stress treatment, i.e. 5 days of drought treat- 
ment. Therefore, this indicated no irreversible damages to photosynthetic reaction centers occurred. After 20 days withholding water, the FG1 clone quickly recovered in a few days (5 days) and FG11 clones are very near to recovery. Moreover, the recovery of photochemistry and down regulation of heat dissipation occurred in the short period. The role of stomatal closure and biochemical processes in decreasing net photosynthetic rates during drought stress is well established. The same hold also in teak clones when drought treatment varies from 0 to 20 days of treatment and after re-hydration. The drought stress-dependent decrease in the content of soluble proteins in the FG1 and FG11 clones studied could be due to enhanced degradation of proteins as a result of protease activity (PALMA et al., 2002) and polysome activity and/or due the generation of ROS (BAISAK et al., 1994; KRAMER and BOYER, 1995). Excess light energy can enhance production of free oxygen radicals, which lead to peroxidation of fatty acids in cell membranes (PARKIN et al., 1989; FoYER et al., 1994). In the present study, drought stress-induced considerable damage on the cellular membranes in both clones is assessed by lipid peroxidation and electrolyte leakage. Increased electrolyte leakage percentage and higher content of MDA, which is the product of membrane lipid peroxidation, were found in the leaves of the teak clones after drought treatment. However, increase in electrolyte leakage percentage was more pronounced in FG11 clones than FG1. This increase in cellular damage appeared to reflect impairments in the equilibrium between the ROS production and antioxidant defence systems, which also indicated that photoprotection and antioxidant substances were not sufficient enough to protect against cell membrane damage caused by ROS. Drought stress-induced damage on the cellular membranes has been reported also in many previous studies (YIN at al., 2005; DUAN et al., 2005; ElsheERY and CAO, 2008; XIAO et al., 2009).

The physiological mechanisms that allow a species to tolerate prolonged periods of drought stress can involve numerous attributes including the accumulation of osmotically active solutes (free amino acid, proline and total soluble sugar), so that turgor and turgor-dependent processes may be maintained during the episodes of dry-down. In this study, FAA content increased under drought treatment, as compared with control. This conforms to earlier reports of YADAV et al. (2005) and MANI-
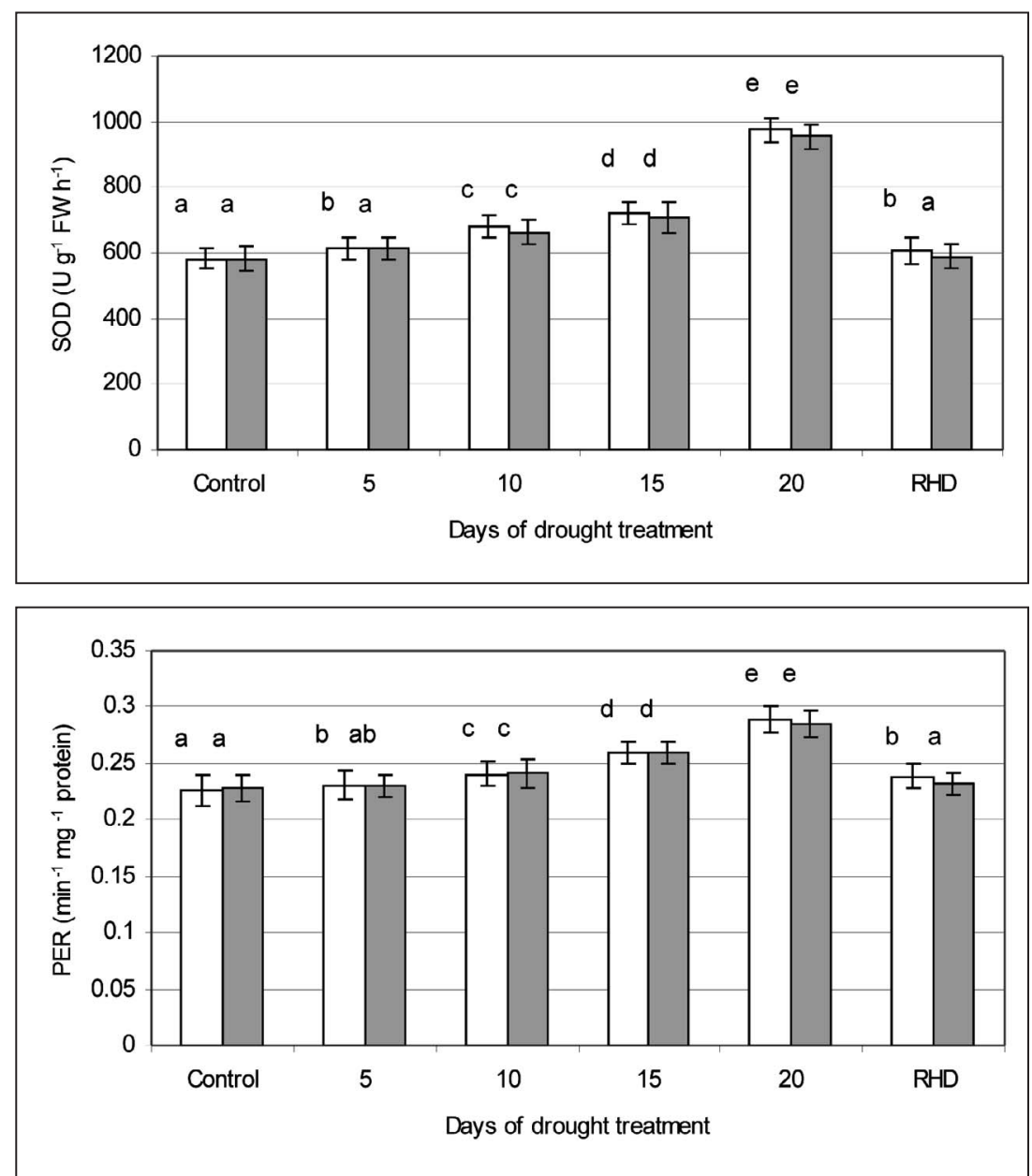

Figure 3. - Activities of superoxide dismutase (SOD) and peroxidase (PER) enzymes in two clones of Tectona grandis (FG1 white bars and FG11 gray bars) on the day before treatment (Control), $5,10,15,20^{\text {th }}$ day since drought treatment and $5^{\text {th }}$ day since re-hydration (RHD). Values followed by the same letter indicate no significant differences at $\mathrm{P}<0.05$ level according to Tukey's test. Each value represents the mean $\pm \mathrm{SE}$ of five replicates. 
VANNAN et al. (2007). Accumulation of amino acids may be due to the hydrolysis of protein and may occur in response to the change in osmotic adjustment of cellular contents (GREENWAY and MuNNS, 1980), an important mechanism that alleviates some of the detrimental effects of water-deficit stress (MORGAN, 1984). Accumulation of free amino acids under water deficit stress indicates the possibility of their involvement in osmotic adjustment, as reported earlier (YADAV et al., 2005; MANIVANNAN et al., 2007; ANJUM et al., 2008). The content of proline, a protective solute in teak leaves increased due to drought treatment in both the clones studied. Proline is an amino acid and known to act as an osmolyte, protecting the plasma membrane integrity (MANsour, 1998), as a sink of energy or reducing power (VERBRUGGEN et al., 1996), as a scavenger of ROS and their derivatives (HoNG et al., 2000; BASHIR et al., 2007) and as a source for carbon and nitrogen (PENG et al., 1996), and thereby helping the plants to tolerate stress effects (MANIVANNAN et al., 2007). In the present teak clonal materials proline accumulation thus appears to be related to mechanisms associated with tolerance to desiccation (MANIVANNAN et al., 2007). Drought treatment also enhanced the accumulation of other compatible solute such as total soluble sugars in both clones. This was in agreement with the results observed in other studies (ELSHEERY and CAO, 2008; XIAO et al., 2009). Correlation between sugar accumulation and osmotic stress tolerance has been widely reported, including transgenic experiments (CHAVES et al., 2003; BARTELS and SUNKAR, 2005). Sugars have different functions in plants from energy storage to signaling, and plants utilize several sugar-based strategies to adapt to environmental stresses (ANDERSON and KOHORN, 2001; Chaves et al., 2003). The current hypothesis is that sugars act as osmotica and/or protect specific macromolecules and contribute to the stabilization of membrane structures (BARTELS and SUNKAR, 2005). Generally, soluble sugar content tends to be maintained in the leaves of drought-stressed plants, although rates of carbon assimilation were partially reduced. The maintenance of soluble sugar content may be achieved at the expense of starch which drastically declines (CHAVES, 1991). Increase in soluble sugar contents through inversion of some carbohydrates may contribute to enhanced desiccation tolerance and allows metabolic activity to be maintained. Overall, in general the higher accumulation of compatible solutes was found in FG1 teak clones.

A variety of abiotic stresses, including drought caused molecular damage to plant cells either directly or indirectly through the formation of ROS. Drought stressinduced generation of ROS triggers activation of components of antioxidative defence system of plants, which comprises both enzymatic and non-enzymatic low molecular weight antioxidants. In the present study, during drought treatment SOD activity continually increased and PER activity also activated in both FG1 and FG11 clones. However the observed higher antioxidant activities of SOD and PER were fond more in the FG1 clones. This results show that the FG1 clones has stronger ability of scavenging ROS to defence stress/or stronger tolerance capacity (SoFo et al., 2004). This fact is re-inforced by the lower levels of lipid peroxidation and electrolyte leakage in the FG1 than those in the FG11 clones. Therefore, the ability to increase the antioxidant SOD and PER activity in order to limit cellular damages might be an important attribute linked to the FG1 clones.

In conclusion, the responses of the two teak clones to drought stress were investigated through some important morphological, physiological and biochemical processes. The results indicate that drought stress causes a pronounced slow down of growth, decreased leaf water status, chlorophyll pigments, soluble protein and increased carotenoids contents and cellular damage in both clones. The rate of photosynthesis, stomatal conductance, transpiration rate and chlorophyll fluorescence in FG1 and FG11 clones were also effectively decreased due to drought stress. Drought stress-induced increased accumulation of osmotically active solutes such as proline, free amino acids and soluble sugars were observed. In addition, antioxidant systems including SOD and PER were also activated by drought treatment. On the other hand, there were significant different responses to drought treatment between the two clones of $T$. grandis. In comparison, FG1 teak clones (high rejuvenation capacity) showed higher resistance to drought than FG11 (low rejuvenation capacity) clones because of stronger photoprotection, osmotic adjustment, less ion leakage during cellular damage and higher activity of antioxidative enzymes in response to drought treatments. Further, both teak clones showed the stable maximum photochemistry during 20 days of withholding and rapid recovery in photochemistry in a few days (5 days) after rehydartion, indicating both clones are quite drought-tolerant on the other hand. Moreover, these differences in drought responses also provide some useful clues for teak improvement programme and may be useful in breeding or genetic engineering for their tolerance to drought stress.

\section{Acknowledgments}

This work was partially supported by World Bank Forest Research Education and Extension Programme (FREEP) and Indian Council of Forestry Research and Education (ICFRE), Dehra Dun, India.

\section{References}

Alscher, R. G., N. ErturK and L. S. Heath (2002): Role of superoxide dismutase (SODs) in controlling oxidative stress in plants. Exp. Bot. 53: 133-141.

ANDERSON, C. M. and B. D. KoHORN (2001): Inactivation of Arabidopsis SIP1 leads to reduced levels of sugars and drought tolerance. J. Plant Physiol. 158: 1215-219.

AnJum, N. A., S. Umar, M. IQBAL and N. A. Khan (2008): Growth characteristics and antioxidant metabolism of moongbean genotypes differing in photosynthetic capacity subjected to water deficit stress. J Plant Inter. 3: $127-136$.

AsADA, K. (1994): Production and action of active oxygen in photosynthetic tissue. In: Causes of photooxidative stress and amelioration of defence system in plants. Eds. C. H. Foyer and P. M. Mullineaux. Boca Raton (FL): CRC Press. pp 77-104. 
AsHraf, M. (2003): Relationships between leaf gas exchange characteristics and growth of differently adapted populations of blue panicgrass (Panicum antidotale Retz.) under salinity or waterlogging. Trends Plant Sci. 165: 69-75.

Ashraf, M., M. Y. Ashraf, A. KHALIQ and E. S. RHA (2004): Growth and leaf gas exchange characteristics in Dalbergia sissoo Roxb. and D. latofolia Roxb. under water deficit. Photosyn. 42: 157-160.

BAISAK, R., D. RANA, P. ACHARYA and M. KAR (1994): Alterations in the activities of active oxygen scavenging enzymes of wheat leaves subjected to water stress. Plant Cell Physiol. 35: 489-495.

BAJJI, M., S. LUTTS and J. M. KINET (2001): Water deficit effects on solute contribution to osmotic adjustment as a function of leaf ageing in three durum wheat (Triticum durum Desf.) cultivars performing differently in arid conditions. Plant Sci. 160: 669-681.

BARNETT, N. M. (1974): Release of peroxidase from soybean hypocotyl cell walls by Selerotium rolfsii culture filtrates. Can. J. Bot. 52: 265-271.

BARTELS, D. and R. SUNKAR (2005): Drought and salt tolerance in plants. Critical Rev. in Plant Sci. 24: 23-58.

BASHIR, F., MAHMOODUZZAFAR, T. O. SIDDIQI and M. IQBAL (2007): The antioxidative response system in soybean plants exposed to Deltamethrin, a synthetic pyrethroid insecticide. Environ. Poll. 147: 94-100.

BATES, L. S., R. P. WALDREN and I. D. TEARE (1973): Rapid determination of free proline for water stress studies. Plant Soil 39: 205-207.

Boyocous, G. J. (1962): Hydrometer method improved for making particle-size analysis of soils. Agro. J. 54: 464-465.

BRADFORD, M. M. (1976): A rapid and sensitive method for the quantitation of microgram quantities of protein utilizing the principle of protein-dye binding. Anal Biochem. 72: 248-254.

Chaves, M. M., J. Flexas and C. Pinheiro (2009): Photosynthesis under drought and salt stress: regulation mechanisms from whole plant to cell. Ann. Bot. 103: 551-560.

CHAVES, M. M. (1991): Effects of water deficits on carbon assimilation. J. Exp. Bot. 42: 1-16.

Chaves, M. M., J. P. Maroco and J. S. Pereira (2003): Understanding plant responses to drought - from genes to the whole plant. Fun. Plant Biol. 30: 239-264.

Cornic, G., J. Ghashghaie, B. Genty and J. M. BRiantais (1992): Leaf photosynthesis is resistant to a mild drought stress. Photosyn. 27: 295-309.

Deleu, C., M. Coustaut, M. F. Niogret and F. Larher (1999): Three new osmotic stress-regulated cDNAs identified by differential display polymerase chain reaction in rapeseed leaf discs. Plant Cell Environ. 25: 979-988.

DEMmig-ADAMs, B. and W. W. AdAMs (1992): Photoprotection and other response of plants to high light stress. Annul Rev. Plant Physiol. Plant Mol. Biol. 43: 599-626.

Dhindsa, R. A., P. Plumb-Dhindsa and T. A. Thorpe (1981): Leaf senescence: correlated with increased permeability and lipid peroxidation, and decreased levels of superoxide dismutase and catalase. J. Exp. Bot. 126: 93-101.

DuAN, B. L., Y. W. Lu, C. Y. Yin, O. JunTtILA and C. Y. Li (2005): Physiological responses to drought and shade in two contrasting Picea asperata populations. Physiol. Plant. 124: 476-84.

Dubois, M., K. A. Gillies, J. K. Hamilton, P. A. Rebers and F. SMiTH (1956): $\underline{\text { A colorimetric method for determi- }}$ nation of sugars and related substances. Anal Chem. 28: 350-356.

Duxbury, A. C. and C. S. Yentsch (1956): Plankton pigment monographs. J. Mar. Res. 15: 19-101.

EPron, D., E. DREYer and N. BREDA (1992): Photosynthesis of oak trees (Quercus petraea (Matt.) Liebl.) during drought under field conditions, diurnal course of net $\mathrm{CO}_{2}$ assimilation and photochemical efficiency of photosystem II. Plant Cell Environ. 15: 809-820.

Flexas, J., J. Bota, J. Galmés, H. Medrano and M. RibasCARBó (2006): Keeping a positive carbon balance under adverse conditions: responses of photosynthesis and respiration to water stress. Physiol. Plant. 127: 343-352.

Flexas, J., A. Diaz-Espejo, J. Galmés, R. Kaldenhoff, H. MEDRANo and M. RiBAS-CARbó (2007): Rapid variations of mesophyll conductance in response to changes in $\mathrm{CO}_{2}$ concentration around leaves. Plant Cell Environ. 30: $1284-1298$.

Foyer, C. H., P. Descourvieres and K. J. Kunert (1994): Protection against oxygen radicals, an important defence mechanism studied in transgenic plants. Plant Cell Environ. 17: 507-523.

Frank, H. A. and R. J. Cogdell (1996): Carotenoids in photosynthesis. Photochem. and Photobiol. 63: 257-264.

Galmés, J., H. Medrano and J. Flexas (2007): Photosynthetic limitations in response to water stress and recovery in Mediterranean plants with different growth forms. New Phytol. 175: 81-93.

GENTY, B., J. M. BRIANTAis and N. R. BAKER (1989): The relationship between quantum yield of photosynthetic electron transport and quenching of chlorophyll fluorescence. Biochem. Biophys. Acta 990: 87-92.

Genty, B., J. M. BRiantais and J. B. V. Dasilva (1987): Effects of drought on primary photosynthetic processes of cotton leaves. Plant Physiol. 83: 360-364.

Gollan, T., N. C. TuRner and E. D. Schulze (1985): The responses of stomata and leaf gas exchange to vapour pressure deficits and soil water content. III. In the sclerophyllous woody species Nerium oleander. Oecologia 65: 356-362.

Grassi, G. and F. MAGNANI (2005): Stomatal, mesophyll conductance and biochemical limitations to photosynthesis as affected by drought and leaf ontogeny in ash and oak trees. Plant Cell Environ. 28: 834-849.

GREENWAY, H. and R. MunNs (1980): Mechanisms of salt tolerance in non halphytes. Annu. Rev. Plant Physiol. 31: 149-190.

Gulias, J., J. Flexas, A. Abadia and H. Medrano (2002): Photosynthetic responses to water deficit in six Mediterranean sclerophyll species: possible factors explaining the declining distribution of Rhamnus ludovici-salvatoris, an endemic Balearic species. Tree Physiol. 22: 687-697.

Hiscox, J. D. and G. F. IsRaelstam (1979): A method for the extraction of chlorophyll from leaf tissue without maceration. Can. J. Bot. 57: 1332-1334.

Hodges, D. M., M. D. John, F. F. Charles and K. P. ROBERT (1999): Improving the thiobarbituric acid-reactive-substances assay for estimating lipid peroxidation in plant tissues containing anthocyanin and other interfering compounds. Planta 207: 604-611.

Hong, Z., K. Lakkineni, K. Zhang and D. P. S. Verma (2000): Removal of feedback inhibition of $\Delta 1$-pyrroline5 -carboxylate synthetase results in increased proline accumulation and protection of plants from osmotic stress. Plant Physiol. 122: 1129-1136. 
Husen, A. (2008a): Stock-plant etiolation causes drifts in total soluble sugars and anthraquinones, and promotes adventitious root formation in teak (Tectona grandis L. f.) coppice shoots. Plant Grow. Reg. 54: 13-21.

Husen, A. (2008b): Clonal propagation of Dalbergia sissoo Roxb. and associated metabolic changes during adventitious root primordium development. New Forest. 36: 13-27.

Husen, A. and M. PAL (2003a): Effect of serial bud grafting and etiolation on rejuvenation and rooting cuttings of mature trees of Tectona grandis Linn. f. Silvae Genet. 52: 84-87.

Husen, A. and M. PAL (2003b): Clonal propagation of Tectona grandis (Linn. f).: effect of IBA application and root regeneration on vertically split cuttings. Silvae Genet. 52: $173-176$.

Husen, A. and M. PAL (2003c): Effect of nitrogen, phosphorous and potassium fertilizers on growth of stock plants of Tectona grandis (Linn. f.) and rooting behaviour of shoot cuttings. Silvae Genet. 52: 249-254.

Husen, A. and M. PAL (2006): Variation in shoot anatomy and rooting behaviour of stem cuttings in relation to age of donor plants in teak (Tectona grandis Linn. f.). New Forest. 31: 57-73.

Husen, A. and M. PAL (2007a): Metabolic changes during adventitious root primordium development in Tectona grandis Linn. f. (teak) cuttings as affected by age of donor plants and auxin (IBA and NAA) treatment. New Forest. 33: 309-323.

Husen, A. and M. PAL (2007b): Seasonal changes in rooting response of hardwood cuttings of teak (Tectona grandis Linn. f.) in relation to drift of total soluble sugar, starch and total nitrogen. Ann. Forest. 15: 11-31.

HusEn, A. and M. PAL (2007c): Effect of branch position and auxin treatment on clonal propagation of Tectona grandis Linn. f. New Forest. 34: 223-233.

ItURBe-OrMaetxe, I., P. R. Escuredo, C. ArReselgor and M. BECANA (1998): Oxidative damage in pea plants exposed to water deficit or paraquat. Plant Physiol. 116: 173-181.

JACKSON, M. L. (1962): Soil and Chemical Analysis. Printce Hall, New Jersey.

Jones, H. G. and J. E. CoRLETt (1992): Current topics in drought physiology. J. Agric. Sci. 119: 291-296.

KHANNA-ChOPRA, R., G. Chaturverdi, P. AgGarwal and S. SinHA (1980): Effect of potassium on growth and nitrate reductase during water stress and recovery in maize. Physiol. Plant. 49: 495-500.

KRAMER, P. J. and J. S. BoYeR (1995): Water relations of plants and soils. San Diego: Academic Press.

KURTZ, I. T. and R. H. BRAY (1945): Determination of total organic and available forms of phosphorus in soil. Soil Sci. 59: 39-45.

LAWLOR, D.W. (1995): The effects of water deficit on photosynthesis. In: Environment and plant metabolism. Flexibility and acclimation. Ed. N. SMIRNOFF. BIOS Scientific Publishers, Oxford, pp 129-160.

LAWLOR, D. W. and G. CoRNIC (2002): Photosynthetic carbon assimilation and associated metabolism in relation to water deficits in higher plants. Plant Cell Environ. 25: 275-294.

LeE, Y. P. and T. TAKAhashi (1966): An improved colorimetric determination of amino acids with the use of ninhydrin. Anal Biochem. 14: 71-77.

LuDLOW, M. M. and R. C. Muchow (1990): A critical evaluation of traits for improving crop yields in water-limited environments. Adv. Agron. 43: 107-153.
MACLACHLAN, S. and S. ZALICK (1963): Plastid structures, chlorophyll concentration and free amino acid composition of a chlorophyll mutant of barley. Can. J. Bot. 41: 1053-1060.

Manivannan, P., C. Abdul Jaleel, B. Sankar, A. KishoREKUMAR, R. Somasundaram, G. M. A. LaKSHMANAN and R. PANNEERselvam (2007): Growth, biochemical modifications and proline metabolism in Helianthus annuus L. as induced by drought stress. Colloids Surfaces B: Biointerfaces 59: 141-149.

Mansour, M. M. F. (1998): Protection of plasma membrane of onion epidermal cells by glycine betaine and proline against $\mathrm{NaCl}$ stress. Plant Physiol. Biochem. 36: 767-772.

MAXwell, K. and G. N. Johnson (2000): Chlorophyll fluorescence - a practical guide. J. Exp. Bot. 51: 659-668.

MorGan, J. M. (1984): Osmoregulation and water stress in higher plants. Annu. Rev. Plant Physiol. 35: 299-319.

MunNé-Bosch, S. and L. Alegre (2000): Changes in carotenoids, tocopherols and diterpenes during drought and recovery, and the biological significance of chlorophyll loss in Rosmarinus officinalis plants. Planta 207: 925-931.

NABIL, I., N. I. Elsheery and K. F. CAO (2008): Gas exchange, chlorophyll fluorescence, and osmotic adjustment in two mango cultivars under drought stress. Acta Physiol. Plant. 30: 769-777.

NiYOGI, K. K. (1999): Photoprotection revisited: Genetic and molecular approaches. Annu. Rev. Plant Physiol. and Plant Mol. Biol. 50: 333-359.

Palma, J. M., L. M. SAndalio, F. J. Corpas, M. C. RomeroPuertas, I. McCarthy and L. A. Del Rio (2002): Plant proteases, protein degradation, and oxidative stress: role of peroxisomes. Plant Physiol. Biochem. 40: 521-530.

Pandey, D. and C. Brown (2000): Teak: a global overview. Unasylva 51: 3-12.

Parkin, K. L., A. Marangoni, R. JACKMAN, R. YADA and D. Stanley (1989): Chilling injury. A review of possible mechanisms. J. Food Biochem. 13: 127-153.

PAtel, M. S. and B. A. Golakia (1988): Effect of water stress on yield attributes and yield of groundnut (Arachis hypogaea L.). Indian J. Agric. Sci. 58: 701-703.

Peng, Z., Q. LU and D. P. Verma (1996): Reciprocal regulation of $\Delta 1$-pyrroline-5-carboxylate synthetase and proline dehydrogenase genes controls proline levels during and after osmotic stress in plants. Mol. Gen. Genet. 253: 334-341.

Polle, A. and H. Rennenberg (1994): Photooxidative stress in trees. In: Causes of photo-oxidative stress and amelioration of defence systems in plants. Eds. C. H. Foyer and P. M. Mullineaux. Boca Raton (FL): CRC Press. pp 199-218.

Prochazkova, D., R. K. Sairam, G. C. SRivastava and D. V. SingH (2001): Oxidative stress and antioxidant activity as the basis of senescence in maize leaves. Plant Sci. 161: 765-771.

Reddy, A. R., K. V. Chaitanya and M. Vivekanandan (2004): Drought-induced responses of photosynthesis and antioxidant metabolism in higher plants. J. Plant Physiol. 161: 1189-1202.

SaIram, R. K., P. S. Desmukh and D. C. SAXena (1998): $\underline{\text { Role of antioxidant systems in wheat genotypes tolerant }}$ to water stress. Biol. Plant. 41: 387-394.

SAwhney, V., I. S. ShoEsRan, A. Kaur and R. Singh (1968): Effects of nitrate application on nitrogen fixation and nodule metabolism in cajanus. Plant Physiol. Biochem. 26: 753-759. 
Saxe, H., G. R. Cannell Melvin, Ø. Johnsen, M. G. Ryan and G. VourLitis (2001): Tree and forest functioning in response to global warming. New Phytol. 149: 369-400.

Socías, F. X., M. J. Correia, M. M. Chaves and H. Medrano (1997): The role of abscisic acid and water relations in drought responses of subterranean clover. J. Exp. Bot. 48: 1281-1288.

Sofo, A., B. Dichio, C. Xiloyannis and A. Masia (2004): Effects of different irradiance levels on some antioxidant enzymes and on malondialdehyde content during rewatering in olive tree. Plant Sci. 166: 293-302.

Streb, P., W. Shang, J. Feierabend and R. Bligny (1998): Divergent strategies of photoprotection in high mountain plants. Planta 207: 313-324.

TEWARI, D. N. (1992): A monograph on teak (Tectona grandis Linn. f.). Dehra Dun, India, International Book Distributors. pp 1-477.

Turner, N. C. and M. M. Jones (1980): Turgor maintenance by osmotic adjustment: a review and evaluation. In: Adaptation of plants to water and high temperature stress. Eds. N. C. TURner and P. J. Kramer. WileyInterscience, New York, pp 87-103.

Verbruggen, N., X. J. Hua, M. M. May and M. VAnMonTAGU (1996): Environmental and developmental signals modulate proline homoeostasis: Evidence for a negative transcriptional regulator. Proc. Nat. Acad. Sci. USA 93: 8787-8791.
WALKLEY, A. and I. A. BLACK (1934): An examination of the Degtjareft Method for determining soil organic matter and a proposed modification of the chromic acid titration method. Soil Sci. 37: 29-38.

WEATHERLEY, P. E. (1950): Studies in the water relations of the cotton plants. I. The field measurements of water deficits in leaves. New Phytol. 49: 81-87.

XiaO, X., F. Yang, S. Zhang, H. Korpelainen and C. Li (2009): Physiological and proteomic responses of two contrasting Populus cathayana populations to drought stress. Physiol. Plant. doi: 10.1111/j.1399-3054.2009. 01222.x

XIAO, X., X. XU and F. YANG (2008): Adaptive responses to progressive drought stress in two Populus cathayana populations. Silva Fenn. 42: 705-719.

YADAV, S. K., N. JYOTHI LAKShMi, M. MAHESWARI, M. VANAJA and B. VENKATESWARLU (2005): Influence of water deficit at vegetative, anthesis and grain filling stages on water relation and grain yield in sorghum. Indian J. Plant Physiol. 10: 20-24.

Yin, C., Y. Peng, R. ZANG, Y. ZHU and C. Li (2005): Adaptive responses of Populus kangdingensis to drought stress. Physiol. Plant. 123: 445-451.

ZHANG, X., N. WU and C. LI (2005): Physiological and growth responses of Populus davidiana ecotypes to different soil water contents. J. Arid Environ. 60: 567-579.

ZHU, J. K. (2002): Salt and drought stress signal transduction in plants. Ann. Rev. Plant Biol. 53: 243-273.

\section{Book-Review}

Der große Zander. Enzyklopädie der Pflanzennamen (2 Bände). Von W. ERhardt, E. Götz, N. BöDECKer und S. SEyBold. 2008. Verlag Ulmer, Stuttgart. 2112 S., 3000 Zeichnungen, geb., ISBN 978-38001-5406-7. 99,00 € [D].

The encyclopaedia has more than twice the number of pages than the dictionary of plant names which is edited by the same publisher. This widened version of the well known Zander (plant name dictionary) is divided into two volumes.

In volume1 plant families and genera are presented. More than 3000 black and white drawings illustrated the description of about 3600 genera, which show characteristic traits of one plant for each genus. Their names are explained and main characteristics are listed. The international code of botanical nomenclature (ICBN) and the international code of cultivated plants (ICNCP) are detailed cited.
In volume 2 more than 25000 species and the most common 7500 varieties are listed. The scientific name, the common German, French and English names are written. Additionally 10000 synonyms are given. On about 450 sides a short biography of all authors is given.

Some mistakes are in this huge book. For example the German Abies names are not following the same rule. In the plant name biographies the author J. RICHMOND Booth (1799-1847) is confounded with JOHN GODFREY Воотн (*1830). A good reference index and a comprehensive figure index close this edition.

By the number of mistakes it seems that the book was produced quickly, however, it is worth to purchase it because of the huge number of species and cultivars.

MiRKo LIESEBACH, Großhansdorf

Herausgeber: Johann Heinrich von Thünen-Institut. Bundesforschungsinstitut für Ländliche Räume, Wald und Fischerei.

Schriftleitung: Institut für Forstgenetik, Sieker Landstraße 2, D-22927 Großhansdorf

Verlag: J. D. Sauerländer's Verlag, Finkenhofstraße 21, D-60322 Frankfurt a. M. Anzeigenverwaltung: J. D. Sauerländer's Verlag, Frankfurt am Main.

Gesamtherstellung: PPPP Norbert Wege e.K., Gladenbach — Printed in Germany. 